International Journal of Management Science and Business Administration

Volume 7, Issue 5, July 2021, Pages 38-42

DOI: $10.18775 /$ ijmsba.1849-5664-5419.2014.75.1003

URL: https://doi.org/10.18775/ijmsba.1849-5664-5419.2014.75.1003

\title{
Bank risk profile and horizons in financing investment projects: a case study of selected banks in Uzbekistan
}

\author{
${ }^{1}$ Rustam Sultanov, ${ }^{2}$ Umidjon Duskobilov \\ ${ }^{1,2}$ Department of Banking, Tashkent State University of Economics, Uzbekistan
}

\begin{abstract}
The article presents the results of risk analysis in financing investment projects. In the example of three commercial banks, the relationship between the factors causing risks and the dynamics of the volume of financing of investment projects was modelled using the two-step generalised method of moments - 2SGMM. According to the results of econometric analysis, among the factors, risk assets, risk profile, interest income and investment activity of banks have a significant positive impact on the dynamics of investment loans.
\end{abstract}

Keywords: banking risks, investment project, loan, Uzbekistan

\section{Introduction}

Banking institutions play an important role in creating an optimal investment climate and provide investment projects with the necessary financial resources. In international practice, banks are viewed as "accumulators of capital", directing the necessary funds to promising sectors of the economy and providing them with financial and consulting services. However, the lessons from the global financial crisis have proved the need for foresight in project financing, the ability to measure existing and potential risks, diversify the investment portfolio and rationally manage investment resources. In particular, the sudden collapse of the Lehman Brothers investment bank - the first victim and signal of the danger of the crisis - was the result of an excessive and irrational burden of portfolio investments and a lack of risk monitoring in the stock market and the economy as a whole, as a result of which risks went unnoticed for years.

Although the basic rules of the global financial system changed after the crisis, the recovery process was slow and complex. The crisis in the stock market first put the financial system in a harsh situation, and its consequences paralysed the industrial sectors, the social and the external sectors. A relatively catastrophic situation was observed in the large investment banks in the US, UK, Germany and Switzerland, with a 92 per cent probability of non-performing investment loans during the second wave of the crisis in August-September 2008.

Even though today the situation in the global economy has stabilised, since last year the consequences of the coronavirus pandemic have had a negative impact on its current stance and further improvement. Against the backdrop of a general economic downturn and mobilisation of resources in the social sphere, investment financing decreases on a global scale. For example, in March last year, the risk rating index (VIX) of the most influential investment banks reached the levels of October 2008 - 65.54 points. In the third quarter of 2020, when the pandemic peaked, revenues of the 13 largest investment banks in the world fell 30 per cent compared to the same period of 2019. The largest loss was in Goldman Sachs, which lost 40.9 per cent of its income. Last year the total volume of investment lending in the world decreased by 2.1 per cent compared to 2019 and amounted to 109 billion US dollars.

As noted above, based on the causes and consequences of the global financial crisis, the International Monetary Fund has taken steps to regulate the lending and portfolio practices of investment banks. In particular, by new financial legislation, banks will be given more freedom, but the demand for bank capital will be tightened. And the Basel Committee on Banking Supervision will be able to effectively handle and report on banking risks. The new standard was put into effect on January 1, 2016, for all banks of international significance and on January 1, 2019, for banks of national significance.

However, despite several requirements and standards, the concentration of investment banks continues to grow. Unfortunately, in the United States alone, there are more than 3,400 investment banks, which account for 46 per cent of 
all issued investment loans in the world.

In addition, the untimely fulfilment of the requirements of the Basel Committee standards by banks of world importance increases the risks in their investment activities. For example, according to the aforementioned standards, banks of international importance are required to have an additional 3.5 per cent requirement on top of their capital adequacy ratio. Unfortunately, in 2020 none of the giant investment banks of global importance was able to meet this requirement. And not a single bank of world importance was found with a 2.5 per cent additional requirement. Only three banks (Citigroup, HSBC and JP Morgan Chase) barely surpassed the 2 per cent barrier. This, in turn, clearly shows that banks have a wide range of risks in project finance, and for the very reason there is a growing need for nonstandard solutions and approaches to minimise their impact.

Therefore, bank risk management in financing investment projects has always been one of the most important issues on the agenda of the global financial system. In addition to practical measures and recommendations developed by countries and international financial institutions for early detection of risks, assessing potential loss and preventing their negative impact, scientific research institutions are conducting large scale research and analysis.

\section{Literature Review}

Bank risk had already moved from the agenda of international financial institutions, governments and central banks to the research focus of academic rounds. Periodical bank crises and frequent inconvenient economic conditions made academia join bank risk management debates. Admittedly, international financial institutions are more concerned about bank risks, and academic rounds are facing a big challenge of keeping pace with them. Especially, International Monetary Fund allocates considerably wider focus on bank risks, their origins, profiles, horizons and particular hazards through both practical and scientific tools.

IMF experts Demirgüç-Kunt and Detragiache (2010) studied the association between the compliance with the Basel Core Principles for effective banking supervision with bank soundness in case of over 3,000 banks in 86 countries. They found that compliance is not robustly linked with bank risks.

Vazquez and Federico (2012) investigated the bank funding structure and its implications for financial stability during global financial crisis for 11,000 banks in the U.S. and Europe ranging from 2001 to 2009. The results show that banks with weaker structural liquidity and higher leverage in the pre-crisis period were more likely to fail afterwards. The likelihood of bank failure also increases with bank risk-taking. In the cross-section, the smaller domestically-oriented banks were relatively more vulnerable to liquidity risk, while the large cross-border banks were more susceptible to solvency risk due to excessive leverage. The results support the proposed Basel III regulations on structural liquidity and leverage, but they suggest that the emphasis should be placed on the latter, particularly for the systemicallyimportant institutions. Macroeconomic and monetary conditions are also shown to be related to the likelihood of bank failure, providing a case for the introduction of a macro-prudential approach to banking regulation.

Amaglobeli et al. (2015) examined the risk factors associated with fiscal costs of systemic banking crises by differentiating immediate direct fiscal costs of government intervention (e.g., recapitalization and asset purchases) and overall fiscal costs of banking crises. They found that both direct and overall fiscal costs of banking crises were high in global financial crisis period in some banks, who relied on external funding. The better quality of banking supervision and the higher coverage of deposit insurance helped alleviate the direct fiscal costs.

The European Central Bank experts Altunbas, Gambacorta and Marques-Ibanez (2014) investigated the effect of relatively loose monetary policy on bank risk in the European Union and the United States. They found that relatively low levels of interest rates over a longer period lead to an increase in bank risk, which suggest that monetary policy is not neutral from a financial stability perspective.

In another research Altunbas, Manganelli and Marques-Ibanez (2011) analyzed the relations between risk and bank business models. They found that banks with higher risk exposure had less capital, larger size, greater reliance on shortterm market funding, and aggressive credit growth. A strong deposit base and greater income diversification helped bank business models to be less risky. According to obtained results, the effect of business models was non-linear and had a different impact on riskier banks.

\section{Methodology}

Based on the abovementined studies, theoretical views and analytical methods recommended by leading economists, an econometric model of banking risks and the attitude of banks to investment financing was developed. Taking into account the specifics of the banking sector in Uzbekistan, when creating the model, a two-stage generalised method of moments (2SGMM) was chosen, which is the most effective and reliable method for dynamic analysis of panel data. 
On the basis of the model, we analyzed the economic and mathematical relationship between the level of investment financing risk at Asaka JSCB, Uzpromstroybank JSCB and Trustbank JSCB in 2016-2020. The analysis was carried out using the EVIEWS 10 econometric analysis program.

It should be noted that the two-stage GMM method is closer to reality in comparison with the one-stage method. This method is widely used for short-term and few observations.

Considering the classical theory of credit and banking risk, the following functional expression for the selected banks was formulated on the basis of the model:

$$
\begin{aligned}
I L D= & \alpha I L D_{i, t-1}+\beta_{1} \text { RWA }_{i, t}+\beta_{2} \mathrm{RPF}_{i, \mathrm{t}}+\beta_{3} \mathrm{ITA}_{\mathrm{i}, \mathrm{t}}+\beta_{4} \mathrm{CAR}_{\mathrm{i}, \mathrm{t}}+ \\
& +\beta_{5} \mathrm{LIQ}_{\mathrm{i}, \mathrm{t}}+\beta_{6} \mathrm{LOR}_{\mathrm{i}, \mathrm{t}}+\beta_{7} \mathrm{GDP}_{\mathrm{t}}+\beta_{8} \mathrm{INF}_{\mathrm{t}}+\eta_{\mathrm{i}}+\varepsilon_{\mathrm{i}, \mathrm{t}}
\end{aligned}
$$

$\mathrm{ILD}_{\mathrm{i}, \mathrm{t}}$ - investment lending volume of $i$ bank in $t$ period, $\mathrm{RWA}_{\mathrm{i}, \mathrm{t}}-$ risk-weighted assets of $i$ bank in $t$ period, $\mathrm{RPF}_{\mathrm{i}, \mathrm{t}}-$ risk profile of $i$ bank in $t$ period, $\mathrm{ITA}_{\mathrm{i}, \mathrm{t}}-$ interest income of $i$ bank in $t$ period, $\mathrm{CAR}_{\mathrm{i}, \mathrm{t}}-$ capital adequacy ratio of $i$ bank in $t$ period, $\mathrm{LIQ}_{\mathrm{i}, \mathrm{t}}-$ liquidity ratio of $i$ bank in $t$ period, $\mathrm{LOR}_{\mathrm{i}, \mathrm{t}}-$ lending operations volume of $i$ bank in $t$ period, $\mathrm{GDP}_{\mathrm{t}}-\mathrm{GDP}$ growth in Uzbekistan in $t$ period, $\mathrm{INF}_{\mathrm{t}}-$ inflation rate in Uzbekistan in $t$ period, $\varepsilon_{\mathrm{i}, \mathrm{t}}-$ standard error.

\section{Result and discussion}

Initially, before the 2SGMM test, the stationarity of the selected variables was checked. In order to determine the stationarity of the variables, a unit root test was carried out and the validity of each variable was checked. Taking into account the dynamism and limited number of observations of the available panel data, the analysis used the HarrisTsavalis unit root test. In the Harris-Tsavalis test, a variable is considered stationary when the conditions for the absence of correlation and the presence of autoregression in the variables are satisfied.

Table 1: Harris-Tzavalis unit root test results

\begin{tabular}{|c|c|c|}
\hline Variables & z-statistics & Stationarity \\
\hline ILD & $-4,0018^{* * *}$ & Stationary \\
\hline RWA & $-7,9987 * * *$ & Stationary \\
\hline PRF & $-8,5841^{*}$ & Stationary \\
\hline ITA & $-6,1097 * * *$ & Stationary \\
\hline CAR & $-5,3265^{* * *}$ & Stationary \\
\hline LIQ & $-3,2893 * * *$ & Stationary \\
\hline LOR & $-4,2944 * *$ & Stationary \\
\hline GDP & $-12,4972 * * *$ & Stationary \\
\hline INF & $-5,8412^{* * *}$ & levels. \\
\hline Note & &
\end{tabular}

Note: $*, * *$ and $* * *$ denotes significance at $10 \%, 5 \%$ and $1 \%$ levels.

The results of the Harris-Tzavalis unit root test showed that the selected variables were stationary at the primary level (U0), there is no unit root, and there is a functional relationship between the variables. Due to the fact that it has a primary level of stationarity, there is no need to check the stationarity of variables in the primary (U1) and secondary (U2) differences. According to the mandatory stationarity conditions, if the variables are stationary at the primary level, the mandatory requirement is considered satisfying and analysis is allowed.

After checking the stationarity of the stiff, the 2SGMM test was carried out (Table 2).

Table 2: Two-step GMM test results 
Rustam Sultanov, Umidjon Duskobilov

Bank risk profile and horizons in financing investment projects: case study of selected banks in Uzbekistan

\begin{tabular}{|l|c|c|c|c|}
\hline \multicolumn{1}{|r|}{ Model } & ILD & RWA & PRF & ITA \\
\hline ILD (-1) & $0,378^{* *}$ & - & - & - \\
\hline RWA (-1) & - & $0,415^{* * *}$ & - \\
\hline PRF (-1) & - & - & $0,227 * * *$ & $0,503 *$ \\
\hline ITA (-1) & - & - & - & $-0,029 * *$ \\
\hline CAR & $-0,091 * * *$ & $-0,052^{* * *}$ & $-0,187 * * *$ & $-0,114 * * *$ \\
\hline LIQ & $-0,128 * * *$ & $-0,119 * *$ & $-0,165 * * *$ & $0,043 * *$ \\
\hline LOR & $-0,069 *$ & $0,096 * * *$ & $0,224 * * *$ & $-0,207 * * *$ \\
\hline GDP & $-0,063 * * *$ & $-0,074 * * *$ & $-0,038^{* *}$ & $-0,049 * * *$ \\
\hline INF & $-0,167 * * *$ & $-0,171^{* *}$ & - \\
\hline
\end{tabular}

Note: $* * *$ and $* * *$ denotes significance at $10 \%, 5 \%$ and $1 \%$ levels.

According to Table 2, the size of the lags of all dependent variables is positive and significant. They have a significant positive effect on the volume of investment loans. In particular, the volume of investment loans increases if the riskweighted assets, risk profile and interest income of the selected banks increase. The most influential factor is the increase in interest income, 1 per cent growth leads to an increase in the volume of other investment loans by 0.5 per cent. Accordingly, an increase in the volume of risk-weighted assets leads to an increase in the volume of investment loans by 0.4 per cent, and the risk profile to an increase by 0.2 per cent. Econometric analysis has proven that all of the major variables cause risk at a distinctly high level.

Among the auxiliary variables, the capital adequacy level, liquidity level, GDP growth and inflation do not stimulate the activities of the selected banks in investment lending. Only the lending activity of banks will have a positive relationship with their investment lending activities.

In order to check the reliability and stability of gained results, we exploited three diagnostic tests. Sargan's test was used to test the adequacy of variables and to confirm the reliability of the results. The Arellano-Bond test showed no autocorrelation. Significance and likelihood levels were tested using Wald's test.

\section{Conclusion}

The conducted theoretical and empirical studies showed that investment lending also creates a risk burden for a bank through increasing risk-weighted assets growth. The interest rate income remains the key funding source of lending. Changes in interest income size leads to fluctuations in bank lending practices. The strong ties exist between bank risk profile and investment lending, as lending operations call for risks. Deriving from these research findings, we may propose following conclusions regarding bank risk management practices in investment lending by local banks in Uzbekistan:

1. Credit risk assessment methods. Local banks measure credit risk with outdated methods like client's credit history and solvency requirements. In international practice banks evaluate credibility of the borrower through more advanced ways, such as credit score, profitability and property analysis, long term financial soundness profile etc.

2. Lending practices. Banks often fail in allocating loans in large projects due to lack of funding sources. In modern banking sector cofinancing, shared and syndicated lending practices are widespread and absolutely applicable to local banking system. It enables banks to share risks and diversify client and loan portfolio.

3. Risk mitigation. After global financial crisis of 2008 all large banks created risk mitigation strategies, including early warning signals, safety nets and risk cushioning systems in consistent with risk, market and financial environment characteristics. The Central Bank is highly recommended to introduce national risk mitigation requirements for banks, operating in local banking environment. 


\section{References}

- Altunbaş, Y., Gambacorta, L., and Marqués-Ibáñez, D. (2014). Does monetary policy affect bank risk. International Journal of Central Banking, 10, pp. 95-136.

- Altunbas, Y., and Manganelli, S. and Marques-Ibanez, D. (2011) Bank Risk During the Financial Crisis: Do Business Models Matter? ECB Working Paper No. 1394.

- Amaglobeli, D., End, N. Jarmuzek, M. and Palomba, G. (2015), From Systemic Banking Crises to Fiscal Costs: Risk Factors (July 2015). IMF Working Paper No. 15/166. Crossref

- Boyd, J., Nicolò, G. and Jalal, A. (2009). Bank Competition, Risk and Asset Allocations. IMF Working Paper No. 09/143. Crossref

- Financial Stability Board (2020). "2020 update of group of global systemically important banks (G-SIBs)". Periodicals. https://www.fsb.org/wp-content/uploads/P111120.pdf

- McKinsey\&Company. (2015). The Future of Bank Risk Management. McKinsey Working Papers on Risk.

- Nicolò, G. and Loukianova, E. (2007). Bank Ownership, Market Structure and Risk. IMF Working Paper No. 07/215. Crossref

- S\&P Global Market Intelligence (2021). Global investment banks' revenue to remain elevated in 2021 but below 2020 highs. Press-release. January 4, 2021.

- Vasquez, F. and Federico, P. (2012). Bank Funding Structures and Risk: Evidence from the Global Financial Crisis. IMF Working Papers No. 12/29. Crossref 